Journal

of Geography,

Politics and Society

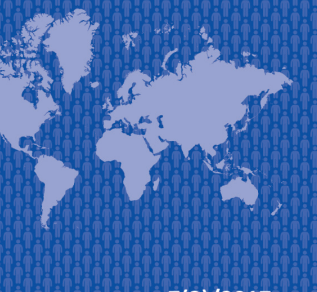

$7(3) / 2017$

\section{Journal of Geography, Politics and Society}

$2017,7(3), 64-74$

DOI 10.4467/24512249JG.17.029.7185

\title{
PARTICULARITIES ESTABLISHED BETWEEN THE LEVEL OF EDUCATION OF THE GRADUATED EDUCATIONAL INSTITUTION OF THE EMPLOYED POPULATION AND ITS DISTRIBUTION ON SECTORS OF ECONOMIC ACTIVITIES IN DEPRESSION OF BEIUS
}

\author{
Mădălina Ropa (1), Lucian Ropa (2) \\ (1) Department of Geography, Tourism and Territorial Planning, University of Oradea, Universitii 1, 410087 Oradea, Romania, \\ e-mail: madalinaropa@yahoo.com (corresponding author) \\ (2) „Nicolae Bolcaș” Vocational Pedagogical High School, Mihai Eminescu 4, 500517 Beiuș, Romania, \\ e-mail: lucianropa@yahoo.com
}

\section{Citation}

Ropa M., Ropa L., 2017, Particularities established between the level of education of the graduated educational institution of the employed population and its distribution on sectors of economic activities in Depression of Beius, Journal of Geography, Politics and Society, 7(3), 64-74.

\begin{abstract}
This study has as main purpose the underlining of the degree of educational specialization of the population depending on the professional economic activities that they develop, on the level of the Depression of Beius in 2011. From the interpretation and analysis of the data is found the presence of some higher values of the persons graduate of higher education in the third sector, followed by the secondary and afterwards by the primary. Also, the urban medium, compared to the rural one, disposes of the best representation of the graduates of higher education, post graduate schools and high schools in the employed population, no matter the economic sector to which we are referring.
\end{abstract}

\section{Key words}

employed population, sectors of activity, level of education, Depression of Beius, illiterate persons.

\section{Introduction}

The analysis of the data regarding the distribution of the employed population on sectors of activity depending on the level of education of the graduated educational institution was performed having as area of reference the Depression of Beius. This is placed in one of the depressions of gulf type from the Western façade of the Occidental Carpathians, overlapping from the administrative point of view over the south-east part of Bihor county (Filimon, 2012; Berindei et al., 1977; Posea et al., 1974).

The population of this depression registers a constant numerical decline in the post communist period, thus subscribing to the specific evolutions of the county area and to the national area (Ancuța, 2008; Boțan, 2010; Dimitriu, 2007; Filimon, 2014; Maier, 2003; Muntele, 1998; Persu, 2012; Rațiu, 2008).

The first stage in accomplishing this geodemographic study was the consulting of a specialty 
bibliography that included the works published by: V. Cucu (2002), A. Ilieș \& M. Stașac (2000), F. Grecu (2000), S. Neguț (2011), L. Nicoară (1999), L.I. Palicica \& M. Palicica (2005), M. Stașac et al. (2016), V. Surd (2004) A. Ungureanu et al. (2002).

The second stage presupposed the processing and interpreting the data offered by the Census of the population and houses from 2011. The values obtained have resulted by dividing the effective number of graduates (attributed to the six levels of education concerned, to which was added the illiterate population) to the population established employed, specific to each sector or field of activity.

\section{The distribution of the employed population on sectors of activity on the general level of Depression of Beius}

From the analysis of the values calculated for the entire depression area it can be seen that the employed population registers in percentage of almost third quarters (70\%) a degree of educational specialization equivalent to the secondary education level (high school, vocational and technical school, gymnasium school). The higher education and implicitly an advanced specialization registers only $17 \%$ of the employed population, and at the opposite pole to be placed those with primary studies (8\%), those without studies graduated, respectively (1\%). These numbers are modified substantially in the moment when is detailed for each of the three sectors of activity, or even in certain examples for each economic activity in part (Fig. 1).

Primary sector of activity includes a population weakly specialized, in the conditions in which only $3.4 \%$ of those that activate in it have graduated higher education schools, and $2.9 \%$ have post graduate schools and of overmen. There is the possibility that a part of this manpower of employed population would not be graduate of some educational institutions congruent with the agricultural, fishy area or silviculture, resulting thus a smaller percentage of the persons with higher education or postgraduate schools of specialty, active in the primary sector. At the opposite pole, from the quantitative point of view is placed the population with gymnasium studies, which hold thus over a third of the total of the employed population in this sector, followed by that with high school studies (19.5\%) and, at a small distance, by that with primary studies (19\%). We should observe in this sector of activity the percentage of $2.1 \%$ attributed to the persons that did not graduate any form of education, but also to the illiterate persons, that hold $1.4 \%$ of the total.

The secondary sector, by the specific of its activities, determined a significant growth of the percentage with higher education in the employed population, up to the number of $14.4 \%$. Also the employed population with post graduate studies, high school

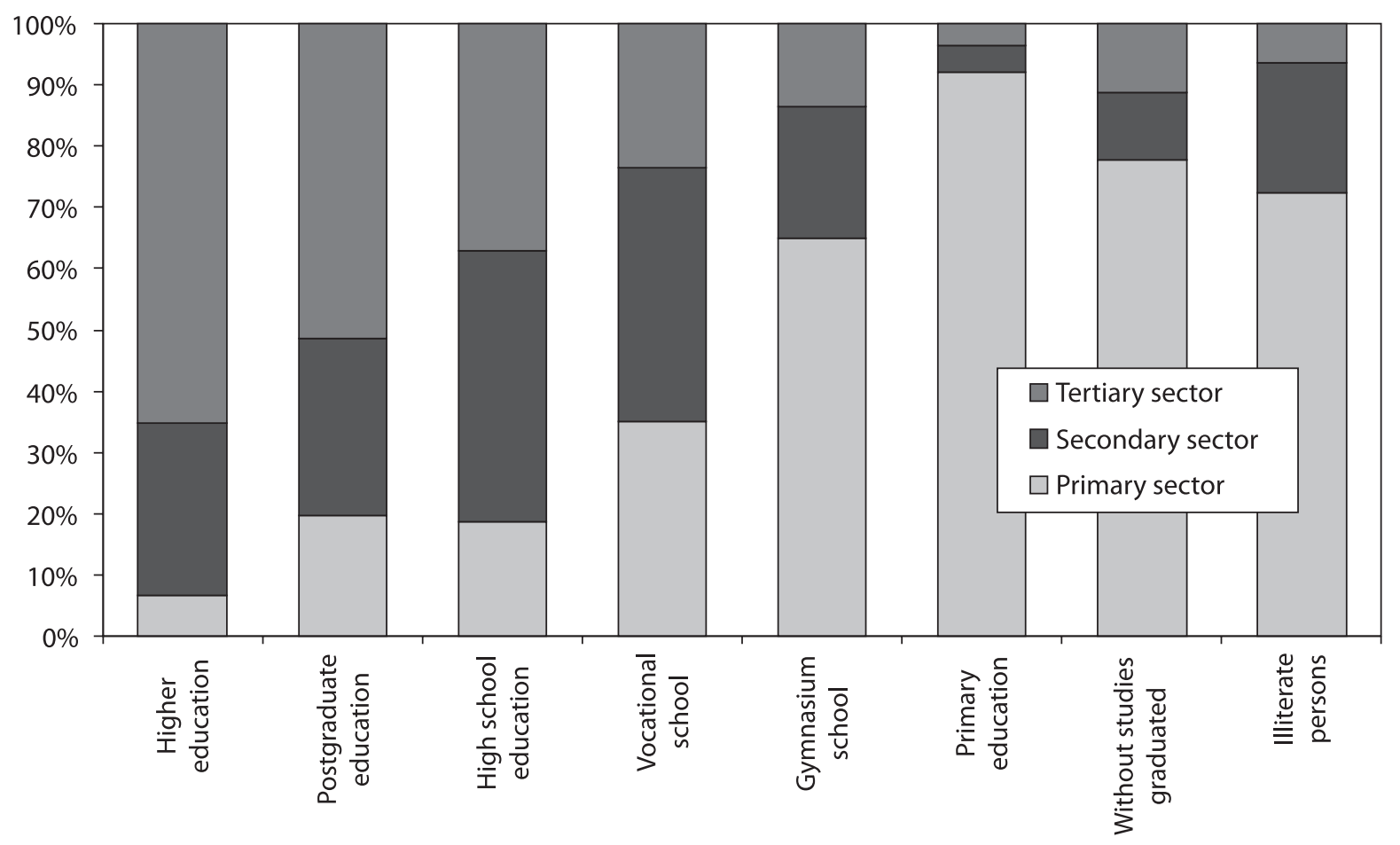

Fig. 1. Distribution of the employed population on sectors of activity, depending on the level of education of the graduated educational institution, on the general level of Depression of Beius, in 2011 (\%)

Source: Recensământul populației și locuințelor din România din anul 2011. 
studies and vocational studies register increases of manpower; for example the graduates of high school studies tend to reach the limit of $50 \%$ of the total. These ascendant evolutions of the number of graduates from the employed population is accomplished against the other levels of education that hold smaller percentages. The persons without studies graduated represent $0.5 \%$, those with primary studies $1 \%$, and the graduates of gymnasium studies $7.3 \%$. The number of illiterate population included in this sector was reduced considerably compared to that specific to the primary sector, up to $0.4 \%$. Detailing on the level of the activities specific to the secondary sector, it appeared many discrepancies, of which we can exemplify the following: the population with higher education studies that activates in the energetic sector has a percentage of $25 \%$, while that from the processing industry, that has similar studies, holds only $14 \%$. Also, of a high specialization of the population manpower is enjoying also the field of extraction energy (20\%), and in constructions would reach the average of $12 \%$ (Fig. 2).

The third sector is characterized by a high percentage of population with a high degree of specialization, in the conditions when a third of the employed population manpower in this sector has higher studies. Compared to the secondary sector, the categories of graduates of secondary and primary education, and those without studies, register a rebound of the percentage held on the third sector.
The differentiations observed in the economical activities included in this sector are more striking than those identified on the level of the secondary sector. Thus, if in the education the percentage of the persons with higher education crosses $65 \%$ of the total, and in administration $50 \%$, in the field of transports it barely crosses the limit of $10 \%$. Also, interested to underline is the percentage registered in the field of health of the persons with post graduate studies (28.4\%), which marks a record value. In this field we identify the highest percentage of the graduates of primary studies $(11 \%)$, which includes the auxiliary personnel, numerously here, by the specific of the activity from the medical units (Fig. 3).

\section{The distribution of the employed population on sectors of activity on the level of dwelling environments}

The urban environment is characterized by a higher degree of specialization of the employed population comparing to the rural one, reported to all the three sectors of activity. Thus, the urban population employed in the primary sector holds in proportion of $15 \%$ higher educational studies, compared to only $2.5 \%$ in case of the rural one. Also, the percentages specific to the urban in regard to the level of education graduated are superior to the rural also in the case of the persons with postgraduate studies,

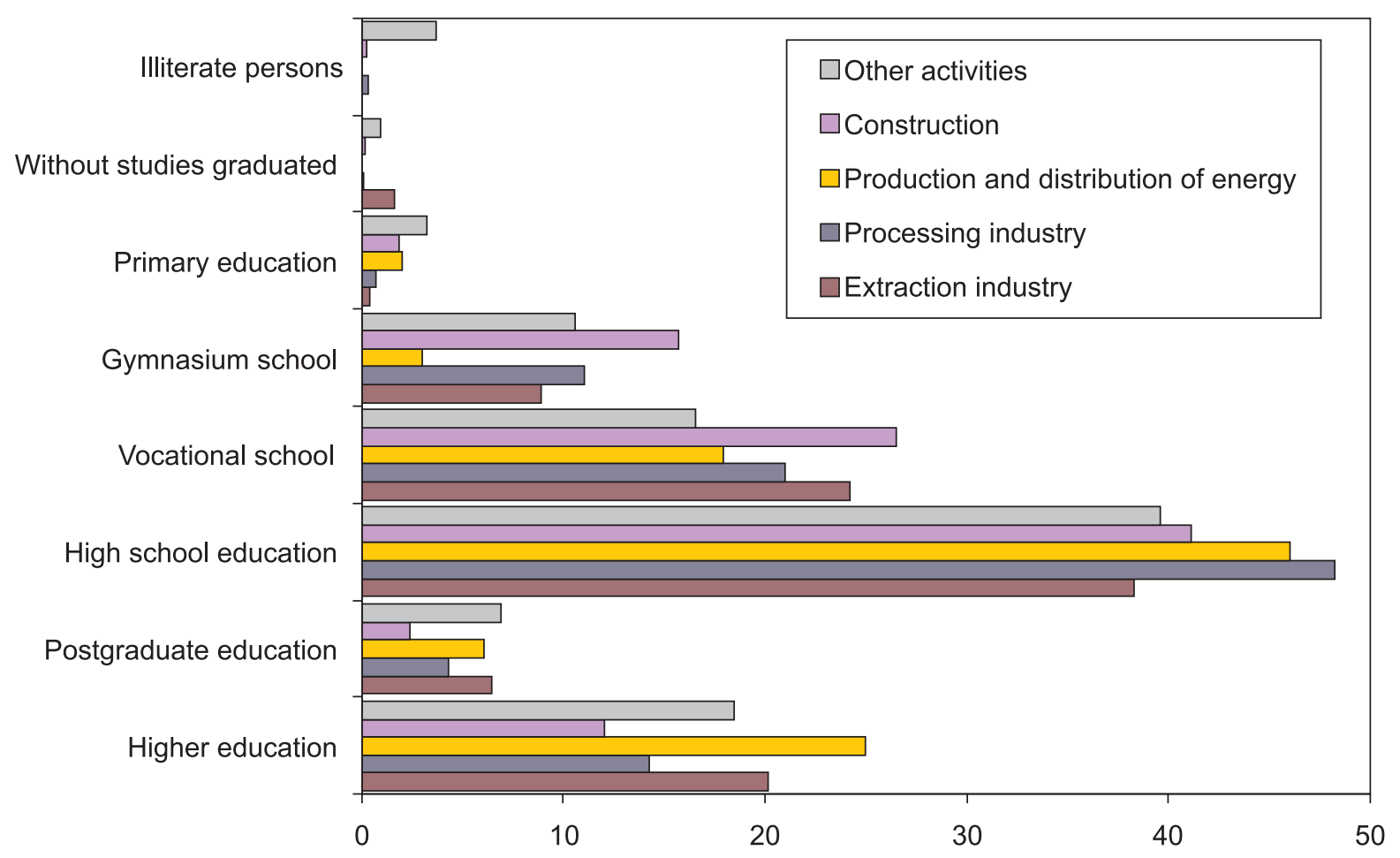

Fig. 2. The distribution of the population depending on the level of education of the graduated educational institution, on economic activities from the secondary sector, on the general level of Depression of Beius, in 2011 (\%)

Source: Recensământul populației și locuințelor din România din anul 2011. 
where the report is of $6 \%$ to $2.6 \%$. The graduates of high school studies from the urban environment received a surplus of approximately $10 \%$ compared to the rural. Only on the level of the graduated persons from vocational schools the registered values are balanced somehow on the level of the dwelling environments, and the rural would have higher percentage in case of the graduates in case of graduates of gymnasium and primary schools. (Fig. 4).

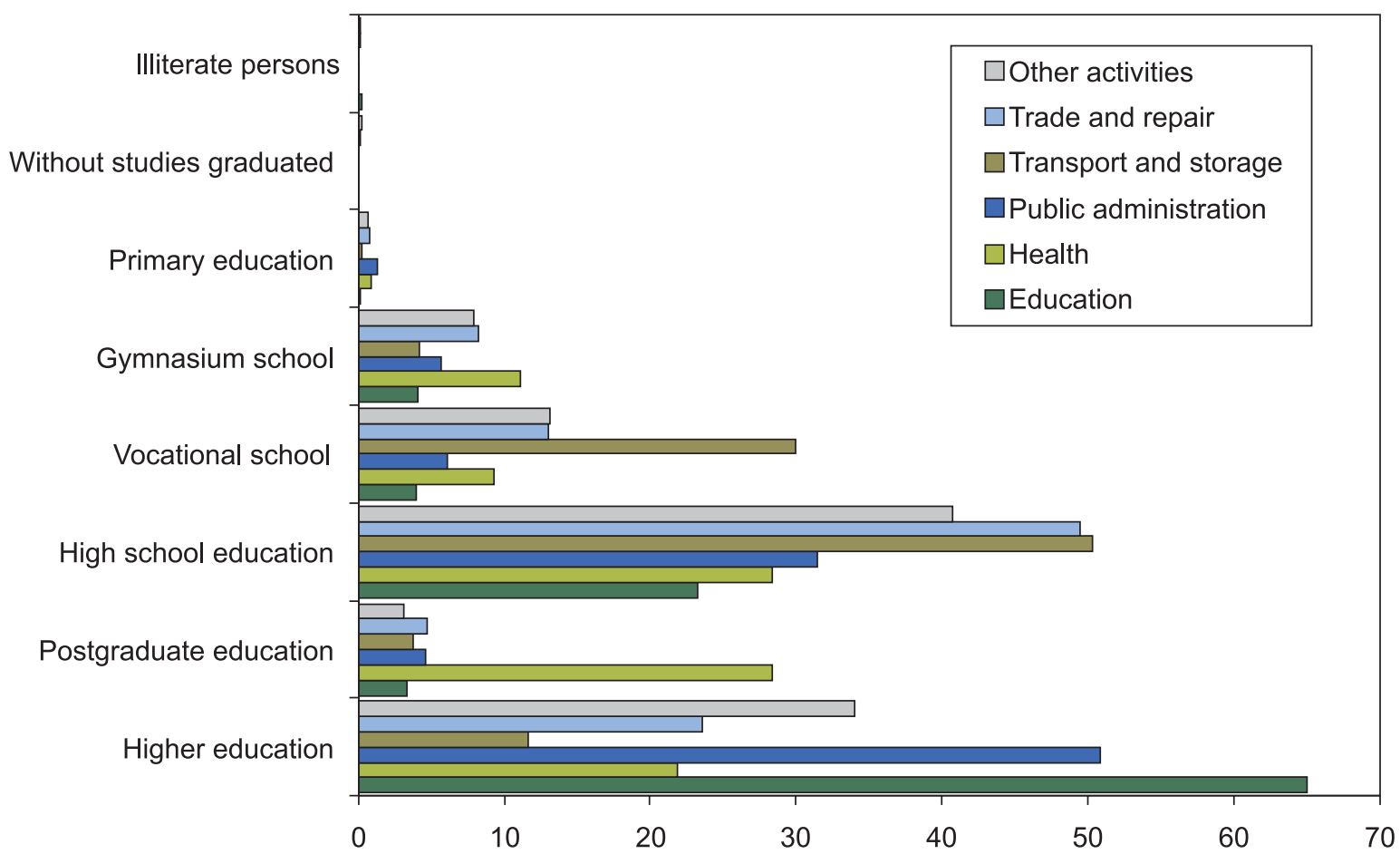

Fig. 3. The distribution of the population depending on the level of education of the graduated educational institution, on economic activities from the third sector, on the general level of Depression of Beius, in 2011 (\%)

Source: Recensământul populației și locuințelor din România din anul 2011.

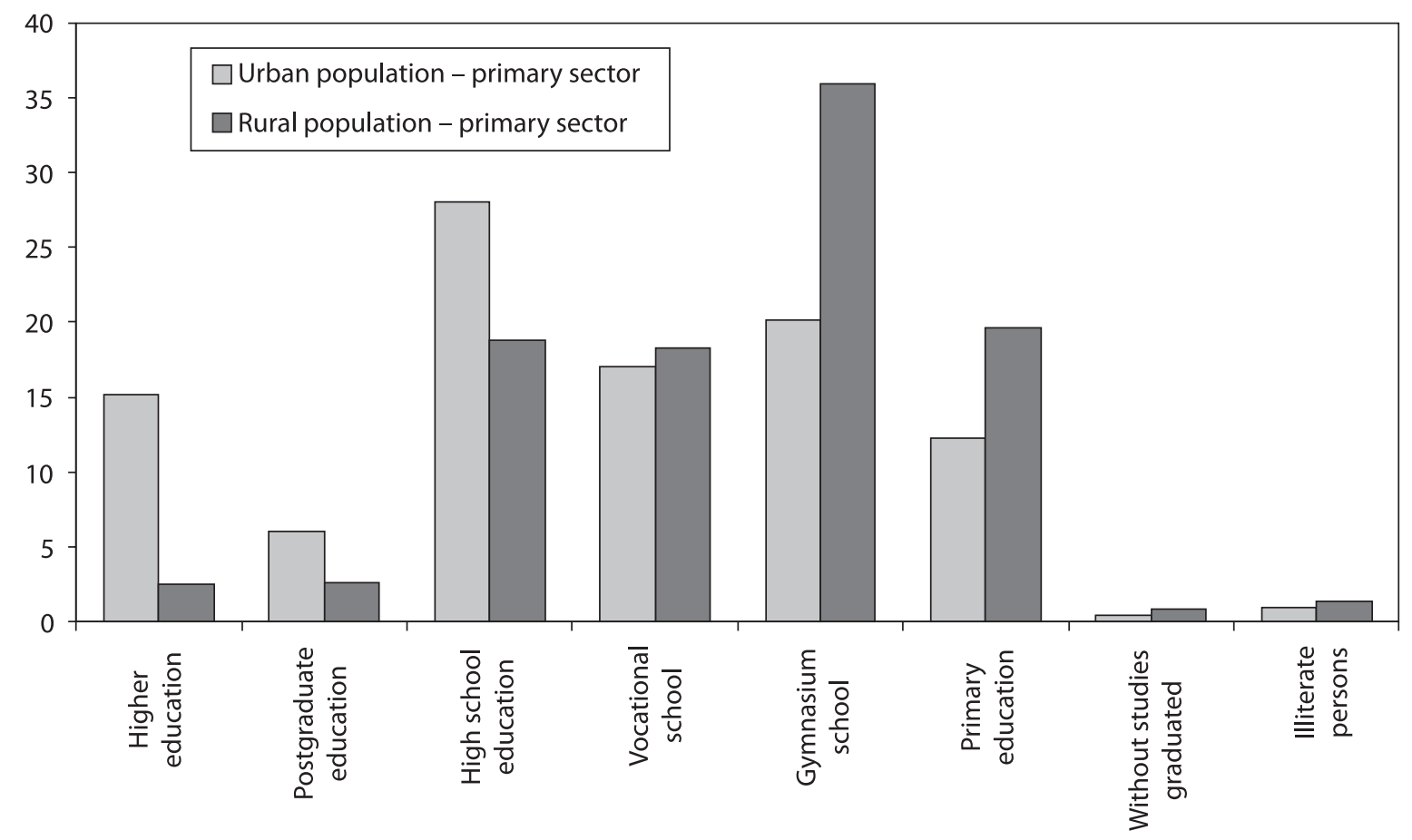

Fig. 4. Distribution of the urban and rural population (employed), in the primary sector, depending on the graduated education, in Depression of Beius, in 2011 (\%)

Source: Recensământul populației și locuințelor din România din anul 2011. 
For example, if on the level of the towns with the highest percentage is that of the graduates of high school studies, in the rural environment the higher percentage is that of the graduates of gymnasium studies. Regarding the persons without graduated studies, we observe that they are more numerous in the rural environment, where they hold $2.2 \%$ from the employed population in the primary sector, compared to $1.3 \%$ which the towns hold. The same trend is registered also in the case of the illiterate persons, who have a more visible presence in the rural, of $1.4 \%$ (148 persons), than in the urban, with $0.9 \%$ (7 persons).

The secondary sector presents values of the employed urban population, who have higher education studies and postgraduate studies, over the specific average of rural, and over the general averages registered in the Depression of Beius. Thus, approximately a fifth of the urban population manpower has university studies, and in the rural this value is halved. These evolutions are marked by the employed population with postgraduate studies, and the high school graduates would have values similar in the two dwelling environment, of $46-47 \%$. Regarding the percentage of the persons with primary studies, this is reduced significantly, to only a percentage for each of the two dwelling environments, and those without studies, included in this sector of activity would be a bit more numerous in the urban, than in the rural area (Fig. 5).
If on the level of the primary and secondary sectors the value discrepancies between the graduates with higher education studies from urban and rural were accentuated, the third sector, by the specific of its activities, determines a reducing of the differences, so that the urban registers a percentage of $40 \%$ and the rural of $28 \%$. Regarding those with primary studies, their percentage is reduced to less than $10 \%$ in both environments of dwelling, in urban falling to even $4.4 \%$ and those without studies would hold in both environments of dwelling only $1 \%$, while the illiterate persons would only mark their presence by the percentage of $0.1 \%$ (Fig. 6).

\section{The distribution of the employed population on sectors of activity, on the level of administrative units}

In order to catch the particularities registered by this type of demographic structure, we detailed and analyzed the date inclusively on the level of the administrative units from this depression area.

The primary sector (Fig. 7), by the characteristics of the specific economic activities that don't need, in a great measure an advanced specialization, registers a very large gap of the values registered by the persons with higher educations studies. Thus, from the maximum registered in Stei $(26.3 \%)$ and Beius $(24.5 \%)$, is falling up to the percentage of only $1 \%$ in

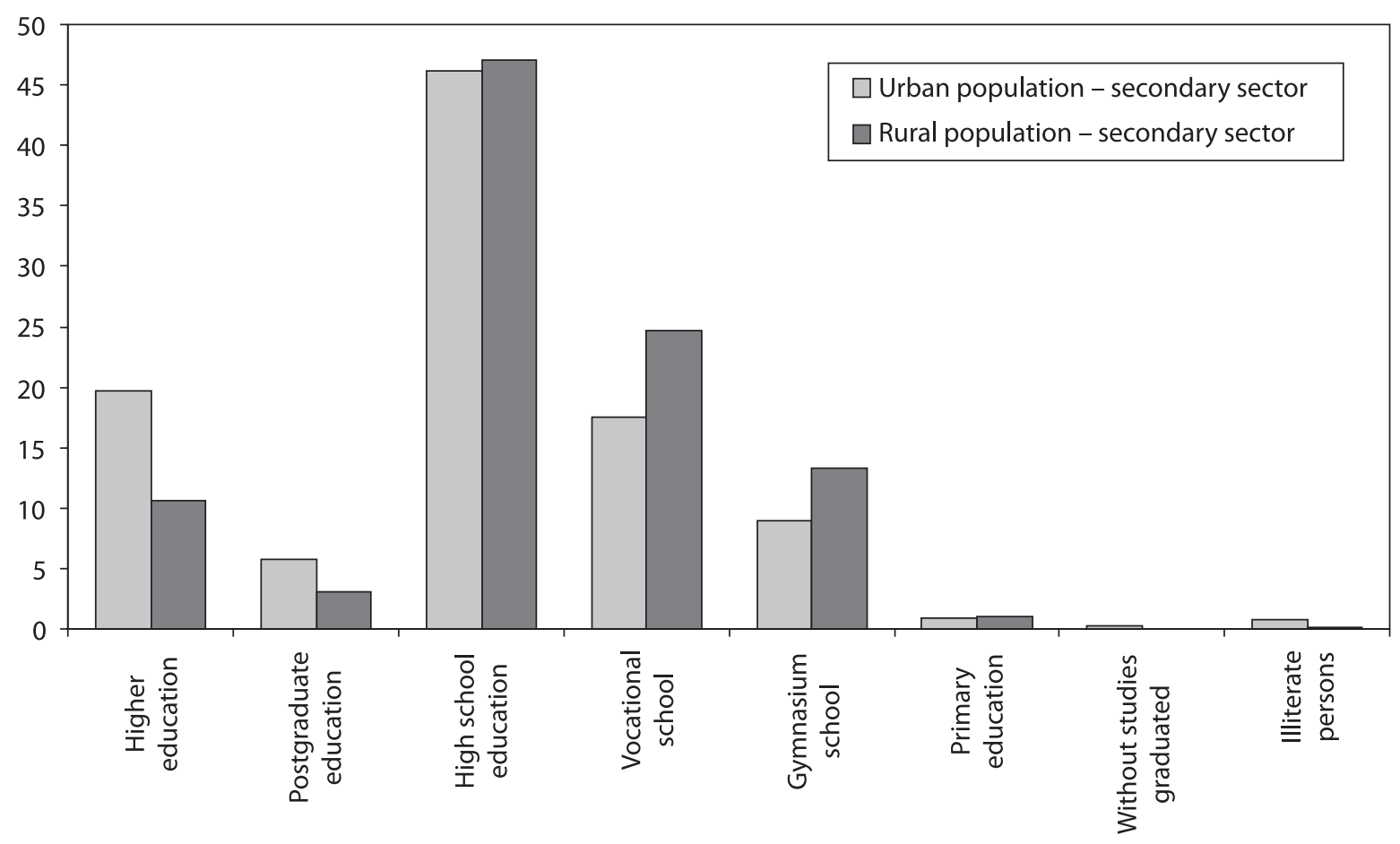

Fig. 5. Distribution of the urban and rural population (Employed), in the secondary sector, depending on the graduated education, in Depression of Beius, in 2011 (\%) 


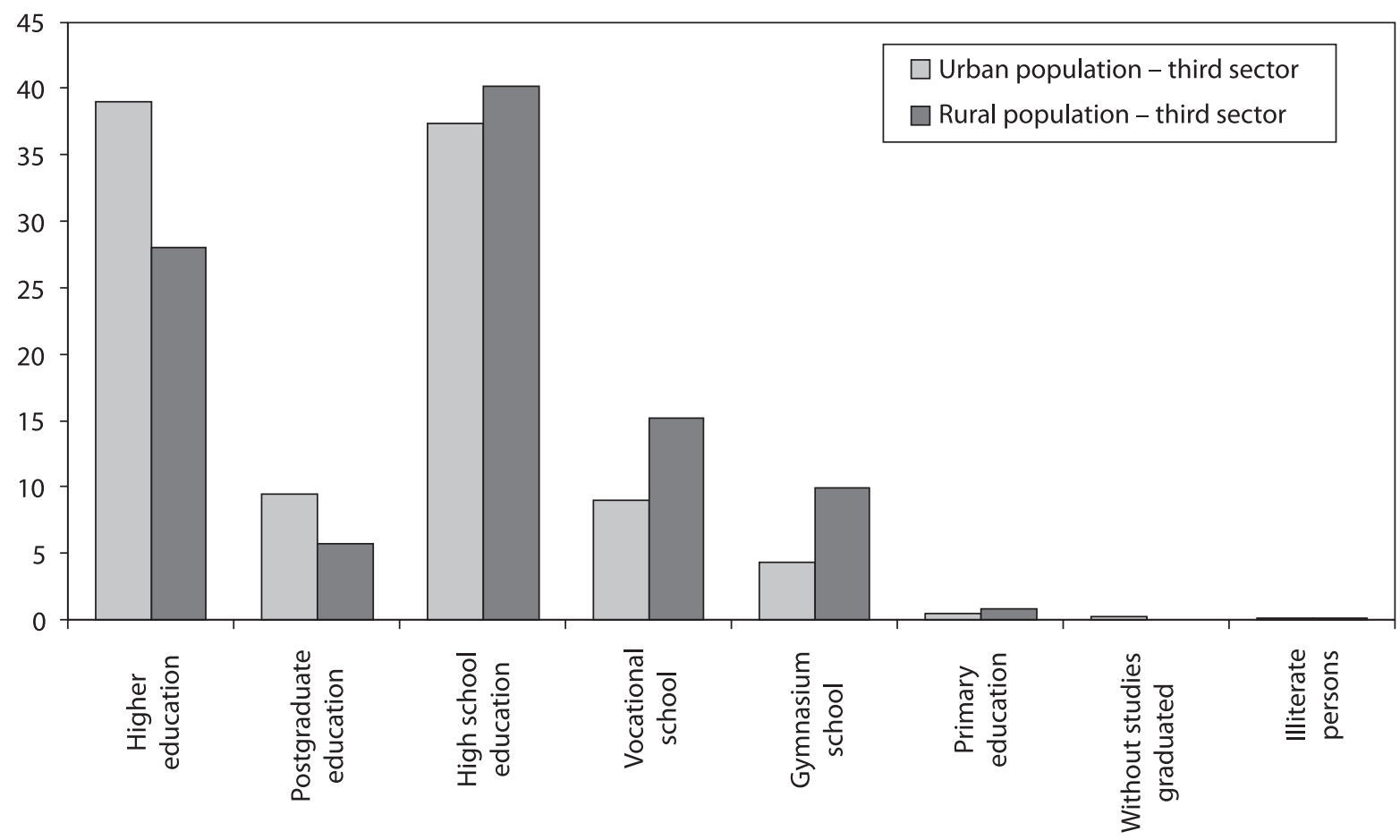

Fig. 6. Distribution of the urban and rural population (Employed), in the third sector, depending on the graduated education, in Depression of Beius, in 2011 (\%)

Source: Recensământul populației și locuințelor din România din anul 2011.

Rosia and $1.1 \%$ in Cabesti. If we are referring only to the population employed, graduates from postgraduate studies, neither in its constituency the values aren't high, the maximum being in the commune Lunca, with $11.3 \%$, and in a series of administrative units it wouldn't reach the limit of one percentage: Roșia, Tărcaia, Căbești etc.

Regarding the distribution of the graduates of high school studies, which are employed in the primary sector, is found that only on the level of the towns Beius and Stei these hold the highest percentage from all the levels of education concerned, with the percentage average of $36 \%, 34.2 \%$, respectively. In some communes from the analyzed depression, this type of graduates register reduced values: of $10.0 \%$ in Rosia, $10.8 \%$ in Căbești, $13.8 \%$ in Pietroasa etc. A particular situation is represented by Nucet, where the persons with vocational school and technical school hold the highest percentage of the categories of graduates, and namely of $30.3 \%$, while Beius, with $11.8 \%$, and Roșia, with $12.0 \%$, is placed at the opposite pole.

Without a doubt, the graduates of gymnasium education from this sector of activity register the highest percentages in the majority of the administrative units, with the exceptions of the towns Beius, Ștei și Nucet. Values that are close to the limit of 50\% are identified in many communes, as: Uileacu de Beiuș, Roșia, Remetea etc.
The persons with primary studies employed in the primary sector of activity are more numerous in Șoimi (29.0\%) Roșia (26.3\%), Pocola (24.4\%), and in Ștei it has only $1.3 \%$ of the total analyzed population. Those without studies register the value of $5.0 \%$ in Nucet, $4.3 \%$ in Uileacu de Beiuș, while in Lazuri de Beius, their presence is not registered.

The illiterate persons that act in this sector mark a reduced presence in majority of the administrative units, in some even being absent (Ștei, Pocola etc.), while in Nucet it reaches $4.1 \%$ of the total population, and in Rieni 3\%.

The secondary sector (Fig. 8), on the level of the administrative units from the Depression of Beius, present numerous particularities regarding the quantitative distribution of the population depending on the level of education graduated. Thus, in a first stage of analysis of the data, is found a more pronounced concentration of the graduates of higher education in the two towns that hold more important industrial units: Beiuș (22.5\%) and Ștei (21.2\%). On the level of the communes, can be identified two situations: in those that are situated in the proximity of the towns previously recalled the percentage of the persons with higher education studies is larger (Lunca: $20 \%$, Rieni: $15 \%$, Pocola: $14 \%$ etc.), while in those that have a peripheral positioning in this depression area, the percentage of the employed persons with higher education studies is very reduced (Roșia: 2.9\%, Șoimi: 6.2\% etc.). 


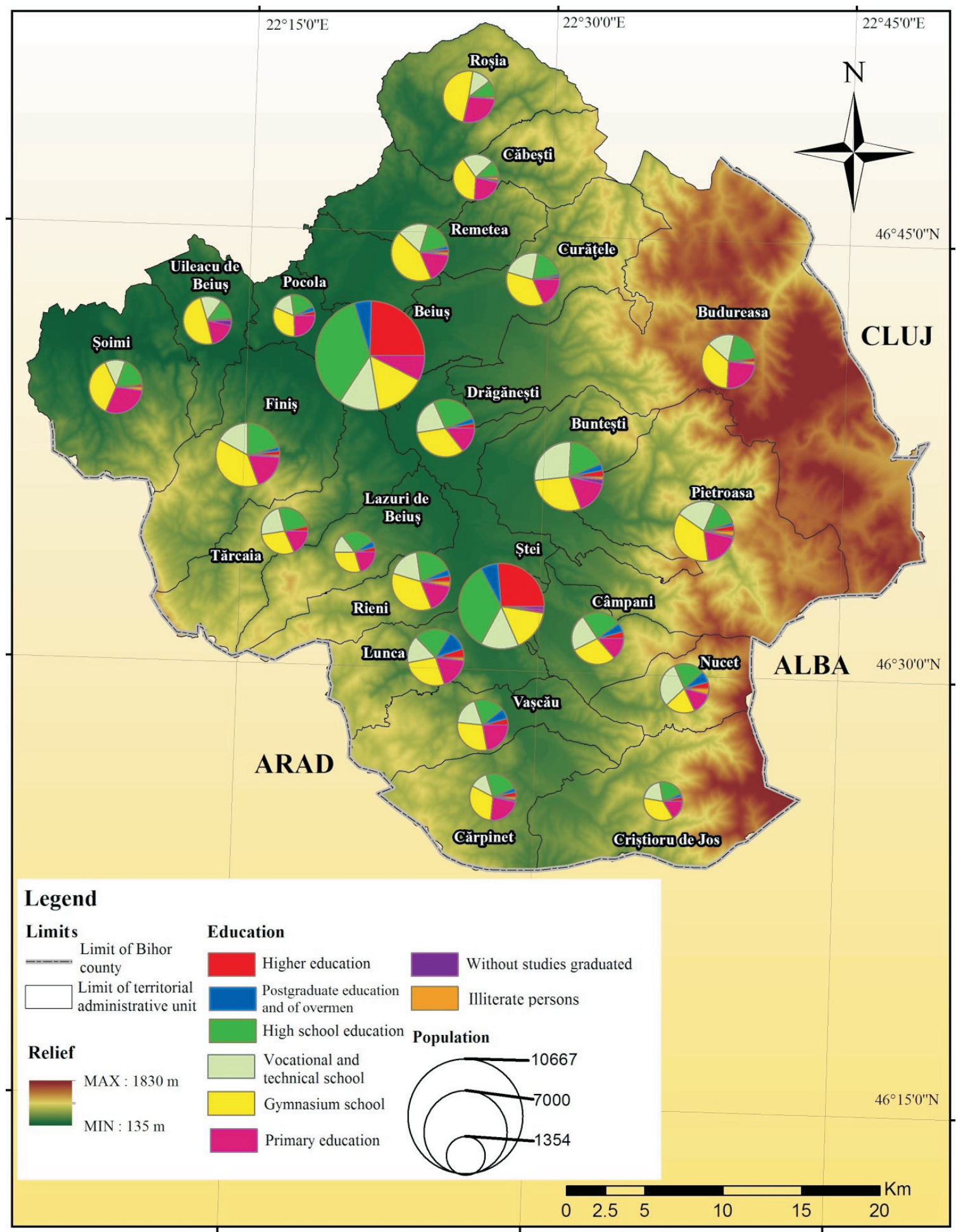

Fig. 7. Distribution of employed population in the primary sector, depending on the level of education of the graduated institution, on the level of the administrative units from the Depression of Beius, in 2011

Source: Recensământul populației și locuințelor din România din anul 2011.

It is surprising the percentage of only $6.5 \%$ of the persons with higher education studies engaged in the secondary economic activities from Nucet town, this being explained by the industrial regress with which the locality is confronted in the present.
From the analysis of the values registered in those 23 administrative units analyzed, we can observe the very high percentage of the persons with high school studies in the secondary sector, percentage over 50\% falling to some communes as: Tărcaia, Drăgănești, Cărpinet etc., and in the four towns from 


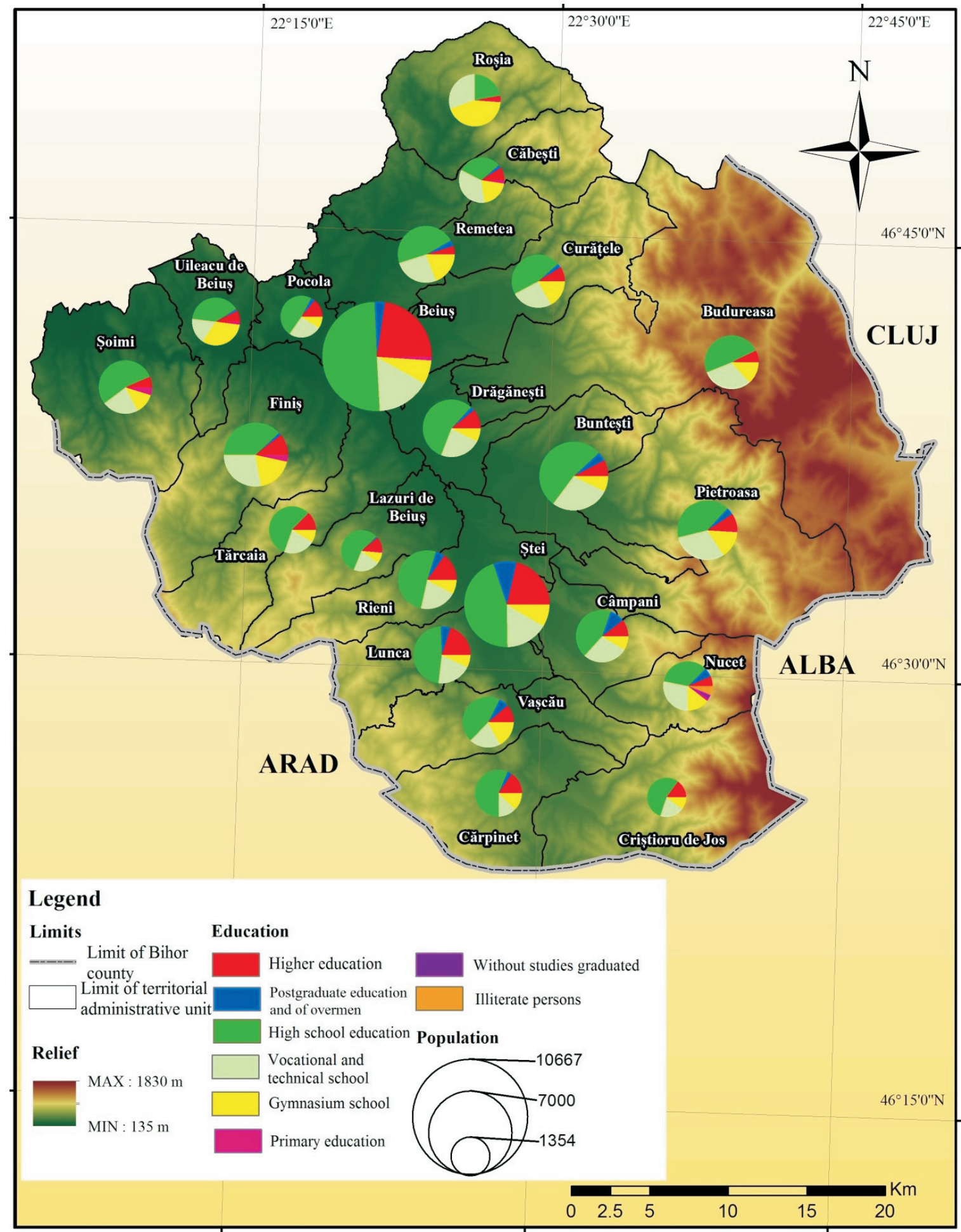

Fig. 8. Distribution of employed population in the secondary sector, depending on the level of education of the graduated institution, on the level of the administrative units from the Depression of Beius, in 2011

Source: Recensământul populației și locuințelor din România din anul 2011.

the Depression of Beius the numbers would reach the average of $50 \%$. Also important percentages are registered by the graduates of vocational and technical schools in the employed population from this sector, being remarked the values of $35.0 \%$ in Căbești, 30.4\% in Roșia, 30.1\% in Budureasa.
The percentage of the persons graduates of gymnasium and primary schools from this sector of activity is reduced, of up to 10 percentage in Stei, Budureasa or Lunca, and in other communes as: Roșia, Uileacu de Beiuș and Căbești the percentage would not cross $20 \%$. 


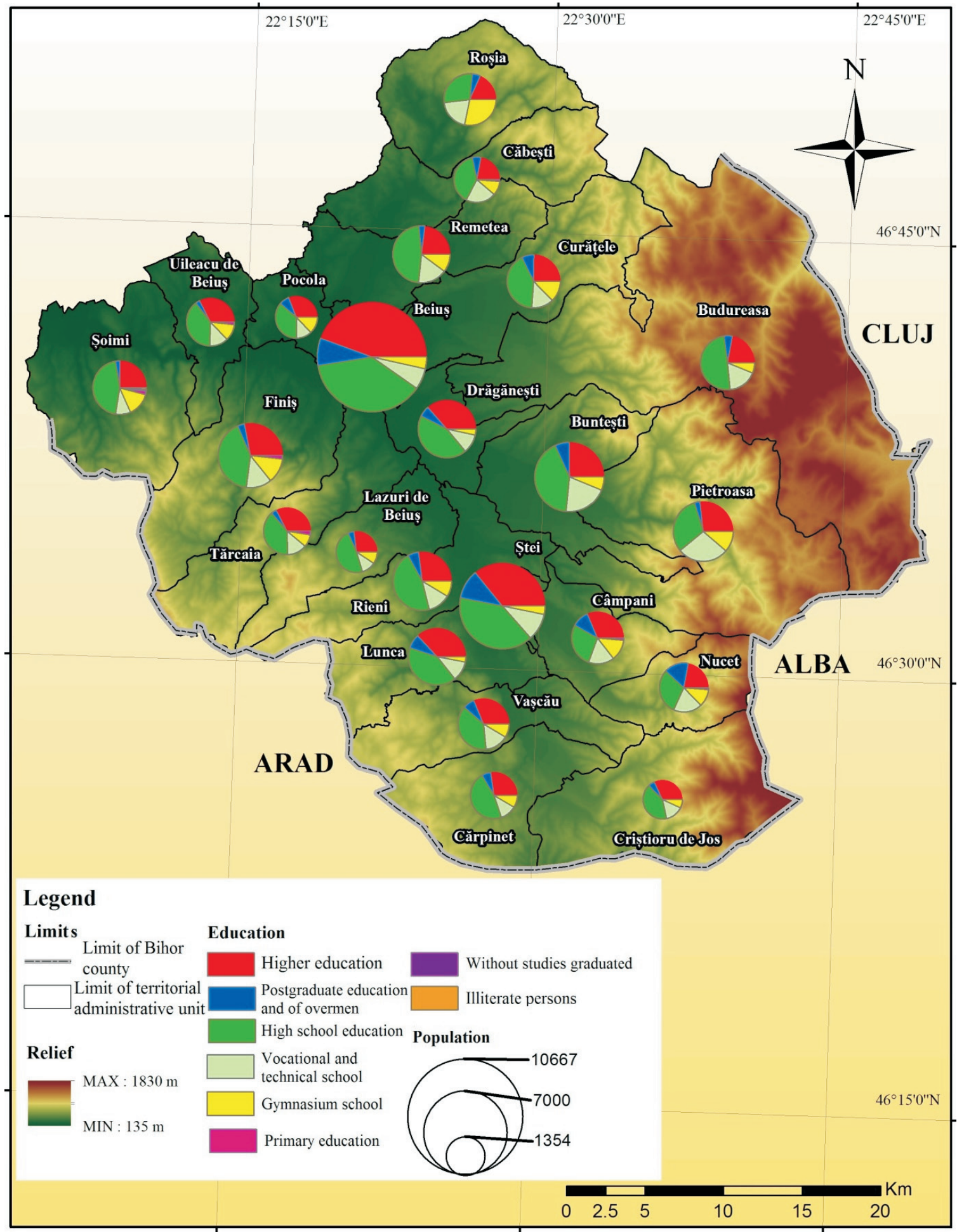

Fig. 9. Distribution of employed population in the third sector, depending on the level of education of the graduated institution, on the level of the administrative units from the Depression of Beius, in 2011

Source: Recensământul populației și locuințelor din România din anul 2011.

The illiterate persons engaged in these activities from the secondary sector register an isolated presence in the depression, more visible being in Nucet (6.1\%), Șoimi, Budureasa, Finiș etc., these being associated also with a more consistent presence of the Rroma community in these administrative units.
Third sector (Fig. 9) by the specific of the economic activities that it includes determines the presence of a high degree of specialization of the population.

Thus, the values that fall back to the persons graduate of higher education studies, on the level of the administrative units are placed over the limit of $20 \%$, with the exception of the commune Rosia 
that registers only a percentage of $19 \%$. At the opposite pole, Beius holds a percentage of this type of graduates of over $44 \%$ from the employed population, being followed by the communes Lunca and Draganesti, each with numbers of over $36 \%$. Also, the third sector involves the increase of the values of the graduates of post graduate school and high schools in the employed population, in the majority of the administrative units, for example, in Budureasa $49 \%$ of the persons employed in the third sector have high school studies, in Lazuri de Beiuș $-48 \%$, in Remetea $-47 \%$ etc.

Regarding the quantitative distribution of the persons with primary studies, without studies or of illiterate persons on the level of administrative unit, is observed either their absence, or a reduced presence in number and isolated.

\section{Conclusions}

The employed population from the Depression of Beius presents a different degree of educational specialization depending on the economic sector in which they act.

Thus, the primary sector is that which includes the most reduced percentage of the persons graduate of higher education studies and, in the same time the highest percentage of those with primary studies, of those without graduated studies, but also of the illiterate persons.

The employed population in the secondary sector holds numerous manpower of graduates of higher education studies, postgraduate, high school and vocational studies, against other types. In the moment when is detailed the level of economic activities specific to this sector is found a better professional training of the persons that activate in the energetic and extracting industry compared to those employed in constructions and processing industry.

The third sector, by the areas of activity represented by the education, health and public administration, determines the increase of the values awarded to the persons with higher education in the employed population. On the level of this sector, the population with primary studies, without graduated studies or illiterate persons barely show their presence, isolated, in some administrative units.

From the comparative analysis of the date, on the level of the dwelling environments we can conclude the fact that the urban environment holds a degree of specialization of the population higher than the rural one, affirmation valid in case of all the three sectors of activity.
Regarding the particularities signalized for the administrative units from this depression area, we can deduce the high percentage of persons with higher education from Beius and Stei, in all the economic sectors, and on the opposite pole would be placed communes as: Roșia, Remetea, Șoimi etc where the population would have more reduced percentage regarding the graduates of higher education studies and higher than those with primary and gymnasium studies.

\section{References}

Ancuța, C., 2008, Studiul geografic al disparităților teritoriale din Banatul românesc, Editura MIRTON, Timișoara.

Berindei, I.O., Pop, G.P, Măhăra, G., Posea, A., 1977, Câmpia Crișurilor, Crișul Repede, Țara Beiușului, în Cercetări în Geografia României, Editura Științifică și Enciclopedică, București.

Boțan, C., N., 2010, Țara Moților. Studiu de geografie regională, Editura Presa Universitară Clujeană, Cluj-Napoca.

Cucu, V., 2002, România. Geografie umană și economică, Editura Transversal, Târgoviște.

Dimitriu, R., 2007, Depresiunea Neamțului - studiu de geografie umană, Editura Universității "Alexandru Ioan Cuza", Iași.

Filimon, C., 2014, Depresiunea Oradea-Bratca. Studiu de populație și așezări, Editura Presa Universitară Clujeană, Cluj-Napoca.

Filimon, L., 2012, Țara Beiușului: studiu de geografie regională, Editura Presa Universitară Clujeană, Cluj-Napoca.

Grecu, F., 2000, Repere ale gândirii în geografie, Editura Universității din București, București.

Ilieș, A., Stașac, M., 2000, Studiul geografic al populației, Editura Universității din Oradea, Oradea.

Maier, A., 2003, Podișul Someșan. Populație și așezări, Editura Gheorghe Barițiu, Cluj-Napoca.

Muntele, I., 1998, Populația Moldovei în ultimele două secole, Editura CORSON, Iași.

Neguț, S., 2011, Geografie umană, Editura Academiei Române, București.

Nicoară, L., 1999, Geografia populației, Editura „Focul Viu”, Cluj-Napoca.

Palicica, L., I., Palicica M., 2005, Resursele umane și pregătirea forței de munca din mediul rural, Editura ORIZONTURI UNIVERSITARE, Timișoara.

Persu, M., R., 2012, Depresiunile subcarpatice oltene dintre Jiu și Bistrița Vâlcii, Editura Universitară, București.

Posea, G., Popescu, N., lelenicz, M., 1974, Relieful României, Editura Științifică, București.

Rațiu, R., 2008, Populația și așezările din Câmpia Someșană (Câmpia Transilvaniei), Editura Casa Cărții de Știință, ClujNapoca.

Recensământul populației și locuințelor din România din anul 2011, http://www.recensamantromania.ro/rezultate-2/ [21.04.2017].

Stașac, M., Filimon, C., Petrea, R., Bulzan, A., 2016, The demographic behaviour of small towns in Romania in the post- 
communist period analyzed through the dynamics of the population. Case study: the small towns in the Bihor county, Romania, Analele Universității din Oradea, 26(2), 210-222.

Surd, V., 2004, Geodemografie, Editura Presa Universitară Clujeană, Cluj-Napoca.

Ungureanu, A., Groza, O., Muntele, I., 2002, Moldova populația, forța de muncă și așezările umane în tranziție, Editura CORSON, lași. 